\title{
Glucose transport and metabolism in rabbit oviduct epithelial cells
}

\author{
L. J. Edwards and H. J. Leese \\ Department of Biology, University of York, Heslington, York YO1 5DD, UK
}

\begin{abstract}
The respiration of intact slices and of isolated epithelial cells from rabbit oviducts was compared. The oxygen consumption of the slices was approximately double that of the cells, but glucose was found to be a preferred substrate in each case. Isolated cells exhibited a Crabtree effect in that glucose concentrations greater than $5.55 \mathrm{mmol} \mathrm{l}^{-1}$ inhibited the respiratory rate. The oviduct epithelial cells grown in primary culture on collagen-impregnated filters formed a polarized monolayer, enabling the transepithelial movement of glucose to be studied under defined conditions. The cells, grown in this manner exhibited an asymmetry characteristic of an epithelium, transporting glucose preferentially in a basal to apical as opposed to apical to basal direction, and corresponding to net glucose transport into the oviduct lumen in vivo. Eighty-one per cent of glucose metabolized under these conditions could be accounted for by the formation of lactate, which appeared predominantly in the basal medium. Glucose was transported across the epithelial cells by facilitated diffusion in association with a smaller, passive component. The rate of glucose transport fell and the transepithelial resistance rose in cells removed and cultured 3 days after mating. The data indicate that rabbit oviduct epithelial cells may be grown as a polarized monolayer in primary culture and that endocrine changes induced in vivo persist under these conditions.
\end{abstract}

\section{Introduction}

The mammalian oviduct consists of an outer muscle layer which surrounds an inner mucosal lining or endosalpinx. The endosalpinx comprises a single layer of epithelial cells and an underlying stroma. The epithelial cells, which border the lumen, are ultimately responsible for the formation of tubal fluid, and together with endosalpinx and whole oviduct explants are widely used in the 'co-culture' of preimplantation embryos. Studies on the various types of cell in the oviduct are therefore required to understand their role in sustaining or enhancing embryo development. This paper is concerned with the metabolism and transport properties of epithelial cells of the rabbit oviduct. Some measurements on the respiration of oviduct tissue slices are also reported.

The metabolism of the rabbit oviduct has been examined previously by measuring the oxygen consumption of whole tissue slices (Mastroianni et al., 1961; Leese et al., 1981). The oxygen consumption was $4.6 \pm 0.59 \mu \mathrm{l} \mathrm{O}_{2} \mathrm{mg}^{-1} \mathrm{dry}$ wt $\mathrm{h}^{-1}$ (Leese et al., 1981), characteristic of a relatively quiescent tissue when compared with organs such as the heart or kidney, which have oxygen consumption values of 30 and 48, respectively (Newsholme and Leech, 1983). However, in the studies on slices of oviduct tissue, no attempt was made to determine which substrates were oxidized, or the relative contributions of epithelial, stromal and muscle cells to the overall oxygen consumption.

McCormack and Glasser (1980) and Kimber et al. (1993) have described methods for isolating epithelial cells of rat and mouse uteri. These techniques were used to separate epithelial cells lining the rabbit oviduct. The respiration of the oviduct epi-

Received 25 January 1993. thelial cells was compared with that of tissue slices from the oviduct.

In the intact oviduct, the epithelial cells are polarized, with their apical surfaces bordering the lumen, and basal surfaces in close contact with the capillary circulation. McCormack and Glasser (1980) and Kimber et al. (1993) showed that isolated, uterine epithelial cells could be grown in primary culture on permeable collagen-impregnated filters. Once in culture, the cells reformed tight junctions and exhibited a polarized morphology similar to that shown in vivo. Dickens et al. (1993) applied this technique to isolated oviduct epithelial cells and showed that they formed a polarized monolayer in primary culture. This method was used to study transepithelial transport of glucose, and its metabolism in a manner not possible with conventional cell culture systems.

\section{Materials and Methods}

\section{Animals}

Dutch rabbits $(2-2.5 \mathrm{~kg})$ were used in this study. In some experiments, 50 iu hCG (Chorion, Intervet Cambridge) in $0.9 \%$ saline was administered i.v. and females were mated with fertile bucks. Rabbits either at oestrus or 3 days after mating were anaesthetized using $10 \mathrm{ml}$ Sagatal $(6 \% \mathrm{w} / \mathrm{v})$ (Vet. Drug Co., Dunnington, York) administered via the marginal ear vein; the oviducts were removed, cleared of fat, slit longitudinally and used in one of the following preparations.

\section{Oxygen consumption of whole tissue slices}

The oxygen consumption of individual $1-2 \mathrm{~mm}^{2}$ slices from the ampulla or isthmus was measured in a Clark oxygen 
electrode (Rank Bros, Bottisham, Cambridge) connected to a pen recorder (Datatrace Gallenkamp, Fisons Instrumentation, Crawley, Sussex). In this method, a magnetic stirrer is present in the incubation chamber which ensures that the medium is aerated and that the slices are well stirred such that their oxygen requirements are likely to be met. The slices, previously stored on ice, were incubated in $2 \mathrm{ml} \mathrm{Krebs-Ringer} \mathrm{bicarbonate}$ medium containing $118 \mathrm{mmol} \mathrm{NaCl} \mathrm{l}{ }^{-1}, 4.74 \mathrm{mmol} \mathrm{KCl} \mathrm{l}^{-1}$, $1.27 \mathrm{mmol} \mathrm{CaCl}_{2} \mathrm{I}^{-1}, 1.18 \mathrm{mmol} \mathrm{KH}_{2} \mathrm{PO}_{4} \mathrm{l}^{-1}, 1.18 \mathrm{mmol}$ $\mathrm{MgSO}_{4} \mathrm{l}^{-1}$ and $25 \mathrm{mmol} \mathrm{NaHCO} \mathrm{1}^{-1}, \mathrm{pH} \mathrm{7.4}$, gassed with $95 \%$ air: $5 \% \mathrm{CO}$ at $37^{\circ} \mathrm{C}$. A linear rate of oxygen consumption was maintained for at least $30 \mathrm{~min}$. Test compounds were normally added in a volume of $10 \mu \mathrm{l}$ after preincubation for $10 \mathrm{~min}$. This enabled the rates after the addition of test compounds to be compared with initial, control rates. Compounds added were: $1 \mu \mathrm{mol}$ carbonyl-cyanide- $m$-chlorophenylhydrazone $1^{-1}$ (CCCP, Sigma, Poole, Dorset), $3.65 \times 10^{-5} \mathrm{mmol}$ antimycin $\mathrm{A} \mathrm{l}^{-1}$ (Sigma), $1 \mathrm{mmol}$ glutamine $\mathrm{l}^{-1}$ (Sigma), $1 \mathrm{mmol}$ acetoacetate $\mathrm{I}^{-1}$ (Sigma), 0.1, 1 and $5.55 \mathrm{mmol}$ glucose $1^{-1}$ (Sigma). After incubation for a further 5-10 min, the tissue was removed, gently blotted and the fresh weight determined. The results were expressed in conventional units of oxygen consumption $\left(\mu \mathrm{l} \mathrm{mg}{ }^{-1}\right.$ dry wt $\left.\mathrm{h}^{-1}\right)$, by assuming that the ratio of dry weight to wet weight was similar to that of fresh oviduct slices: $0.25 \pm 0.02$ for ampulla and $0.27 \pm 0.01$ for the isthmus (Leese et al., 1981).

\section{Isolation of rabbit oviduct epithelial cells}

The method of Dickens et al. (1993) was used. Oviducts were removed, slit longitudinally and washed in $\mathrm{Ca}^{2+}$ - and $\mathrm{Mg}^{2+}$-free Hanks' Balanced Salt Solution (HBSS; Gibco, Grand Island, NY). The epithelial cells were separated by incubation in $0.5 \%$ trypsin type III (Sigma) and $2.7 \%$ pancreatin (Gibco) for $\mathrm{I} \mathrm{h}$ at $4^{\circ} \mathrm{C}$, followed by $\mathrm{I} \mathrm{h}$ at room temperature. The enzyme suspension was washed twice in HBSS and vortexed for $10 \mathrm{~s}$. The pooled supernatant was centrifuged for $5 \mathrm{~min}$ at $500 \mathrm{~g}$ and the pellet resuspended in HBSS. This washing procedure was repeated three times.

\section{Oxygen consumption of isolated epithelial cells}

The cells were resuspended in Krebs-Ringer bicarbonate and gassed with $95 \%$ air: $5 \% \mathrm{CO}_{2}$ at $37^{\circ} \mathrm{C}$, containing $2.5 \%$ albumin (ICN Biochemicals Inc., Cleveland, Ohio), to produce a cell suspension of $4 \times 10^{6} \mathrm{cells} \mathrm{m}^{-1}$. The suspension was stored in a flat-bottomed flask on ice. Two hundred microlitres were incubated in a Clark oxygen electrode as described for the tissue slice preparation and the response to the addition of glucose concentrations of $0.1,1,2.5,5.55,7.5$ and $10 \mathrm{mmol} \mathrm{l}^{-1}$ recorded. It was necessary to determine the dry weight of the isolated epithelial cells so that the oxygen consumption could be expressed as $\mu \mathrm{l} \mathrm{O}_{2} \mathrm{mg}^{-1}$ dry wt $\mathrm{h}^{-1}$. This was determined by measuring the protein content using a modified method of Bradford (1976) and relating the values from fresh weight to dry weight; $1 \times 10^{6}$ cells were found to be equivalent to $1.31 \mathrm{mg}$. Cell viability was assessed before and after each experiment using the trypan blue exclusion test (Seglen, 1976). Epithelial cells were incubated for $5 \mathrm{~min}$ in $0.4 \%$ trypan blue.
Cells that excluded the dye were assumed to have an intact plasma membrane. Ninety to ninety-five per cent of the cells were found to be viable on this basis.

\section{Culture of the oviduct epithelial cells}

The cell culture of isolated epithelial cells was performed according to the method of Dickens et al. (1993). The cells were resuspended in $10 \mathrm{ml}$ culture medium, gassed with $95 \%$ air: $5 \%$ $\mathrm{CO}_{2}$. The composition of the medium was as follows: $15 \mathrm{ml} \mathrm{Hams}$ F-12 Nutrient Medium (Sigma), $15 \mathrm{ml}$ Dulbecco's modified Eagle's medium (Sigma), $0.03 \mathrm{~g}$ BSA (ICN Immunobiologicals Inc.), $0.8 \mathrm{ml}$ penicillin/streptomycin (Sigma), $0.77 \mathrm{ml}$ heat inactivated fetal calf serum (Sigma), $0.77 \mathrm{ml} \mathrm{Nu}$ serum (Flow Laboratories, Ontario) and $200 \mathrm{mmol}$ glutamine (Sigma).

Two hundred and fifty microlitres of the cell suspension $\left(4 \times 10^{6}\right.$ cells $\left.\mathrm{ml}^{-1}\right)$ was plated onto porous, collagenimpregnated filters (Cellagen discs CD-24, $14 \mathrm{~mm}$ diameter: ICN Biochemicals); $450 \mu \mathrm{l}$ of neat culture medium was added to the basal side. The filters were placed in Nunclon dishes, incubated in an atmosphere of $95 \%$ air: $5 \% \mathrm{CO}_{2}$ at $37^{\circ} \mathrm{C}$ and the medium was changed daily. The oviduct epithelial cells took on average 2 days to form a confluent monolayer. Epithelial cells derived from animals either at oestrus or 3 days after mating were treated in the same way.

\section{Metabolism of the oviduct epithelial cells in culture}

Serial samples $(50 \mu \mathrm{l})$ of culture media were taken at intervals of $24 \mathrm{~h}$ for a period of 17 days. Glucose and lactate concentrations in the samples were assayed using an automated technique (COBAS MIRA: Roche Instruments, Welwyn Garden City). Glucose was assayed using the God-Perid Test Combination (Boehringer Mannheim UK, Diagnostics and Biochemicals Ltd, Lewes, East Sussex, UK) to produce a coloured complex and lactate by the formation of NADH from $\mathrm{NAD}^{+}$, as described by Leese and Bronk (1972).

\section{Electrical resistance measurements}

The transepithelial resistance and potential difference were measured using an Endohm resistance meter (World Precision Instruments, Evom, Owslebury, Hampshire) to assess the confluence and integrity of the cultures. Krebs-Ringer bicarbonate $(0.2 \mathrm{ml})$ was added to the apical side of the filter and $2 \mathrm{ml}$ to the basal. A silver-silver chloride electrode was then placed on either side of the filter and readings taken for $5 \mathrm{~min}$ at $37^{\circ} \mathrm{C}$. Filters exhibiting a resistance of $300 \mathrm{ohms} \mathrm{cm} \mathrm{cm}^{-2}$ or greater were used in subsequent experiments. The meter was calibrated by recording the resistance and potential difference of a blank filter, i.e. in the absence of epithelial cells.

\section{Transport studies of the cultured epithelium}

Modified Ussing chambers consisting of a Perspex waterjacketed chamber at $37^{\circ} \mathrm{C}$ were used to observe the transport properties of the epithelium. A filter containing confluent cells was washed free of culture medium with Krebs-Ringer bicarbonate and then clamped between the two sides of the chamber, 
thereby allowing access to both the apical and basal compartments. A known volume of Krebs-Ringer bicarbonate was placed on either side of the filters $(2.55 \mathrm{ml}$ to the apical side and $2.35 \mathrm{ml}$ to the basal) and gassed with $95 \%$ air: $5 \% \mathrm{CO}_{2}$ throughout the experiment. D-Glucose ( 1 or $5.55 \mathrm{mmol} \mathrm{l}^{-1}$ ) was added to either or both sides of the filter. Serial samples $(50 \mu \mathrm{l})$ were taken at intervals of $15 \mathrm{~min}$ for the entire $150 \mathrm{~min}$ incubation and D-glucose was assayed as previously described.

In separate experiments, run in parallel, two filters were prepared with $5.55 \mathrm{mmol}$ glucose $1^{-1}$ introduced to the basal side and Krebs-Ringer bicarbonate to the apical side. To one filter only, $0.5 \mathrm{mmol}$ phloretin $1^{-1}$ (Sigma) was added to both sides, thereby creating a control and test situation. A simultaneous study was also carried out on the transepithelial movement of L-glucose. A mixed solution of $5.55 \mathrm{mmol} \mathrm{D}$ and L-glucose $\mathrm{l}^{-1}$ was added to the basal compartment, while the apical side was exposed to Krebs-Ringer bicarbonate solution. A trace of $\mathbf{L}-\left[\mathrm{I}^{14} \mathrm{C}\right]$ glucose (Amersham, Aylesbury, Buckinghamshire) was added to the basal side of the test filter. $\mathrm{L}-\left[\mathrm{x}^{14} \mathrm{C}\right]$ glucose samples were measured on a Rack Beta 1216 Liquid Scintillation Counter.

\section{Statistical analysis}

The results are expressed as means \pm SEM. The significance between mean values was assessed by Student's $t$ test.

\section{Results}

\section{Respiration of whole tissue slices}

Oxygen was consumed linearly for at least $30 \mathrm{~min}$. The mean oxygen consumption of the ampulla slices was $5.71 \pm 0.23 \mu \mathrm{l}$ $\mathrm{O}_{2} \mathrm{mg}^{-1}$ dry wt $\mathrm{h}^{-1}(n=43)$, while that of slices of isthmus was $5.48 \pm 0.10 \mu \mathrm{l} \mathrm{O}_{2} \mathrm{mg}^{-1}$ dry wt $\mathrm{h}^{-1}(n=48)$. There was no significant difference in the consumption of oxygen between the two regions. The addition of antimycin $\mathrm{A}$, an inhibitor of electron transport between cytochrome $b$ and cytochrome $c_{1}$, reduced the rate of oxygen uptake to $2.92 \mu \mathrm{I} \mathrm{O}_{2} \mathrm{mg}^{-1}$ dry wt $\mathrm{h}^{-1}(P<0.05)$ while CCCP, a protonephric uncoupler, increased the rate to $8.55 \mu \mathrm{O}_{2} \mathrm{mg}^{-1}$ dry wt $\mathrm{h}^{-1}$ (Fig. 1). Of the potentially blood borne respiratory substrates tested (glucose, glutamine and acetoacetate), only glucose caused a significant increase in the respiratory rate $(P<0.01)$. At a glucose concentration of $5.55 \mathrm{mmol} \mathrm{l}^{-1}$, the metabolic rates of the ampulla and isthmus slices were increased by $99 \%$ and $120 \%$, respectively.

\section{Respiration of isolated epithelial cells}

The isolated epithelial cells showed similar qualitative responses to the tissue slices. The oxygen consumption under controlled conditions was $2.92 \pm 0.22 \mu \mathrm{IO}_{2} \mathrm{mg}^{-1}$ dry wt $\mathrm{h}^{-1}$ $(n=54)$. Glucose, at a concentration of $5.55 \mathrm{mmol} \mathrm{l}^{-1}$, significantly increased the oxygen consumption to $5.12 \mu \mathrm{O}_{2} \mathrm{mg}^{-1}$ dry wt $h^{-1}(P<0.001)$ (Fig. 2). Increasing glucose concentration to $10 \mathrm{mmol}^{-1}$ resulted in a significant reduction in the oxygen consumption, to $1.74 \mu \mathrm{O}_{2} \mathrm{mg}^{-1}$ dry wt $\mathrm{h}^{-1}$ $(P<0.001)$.

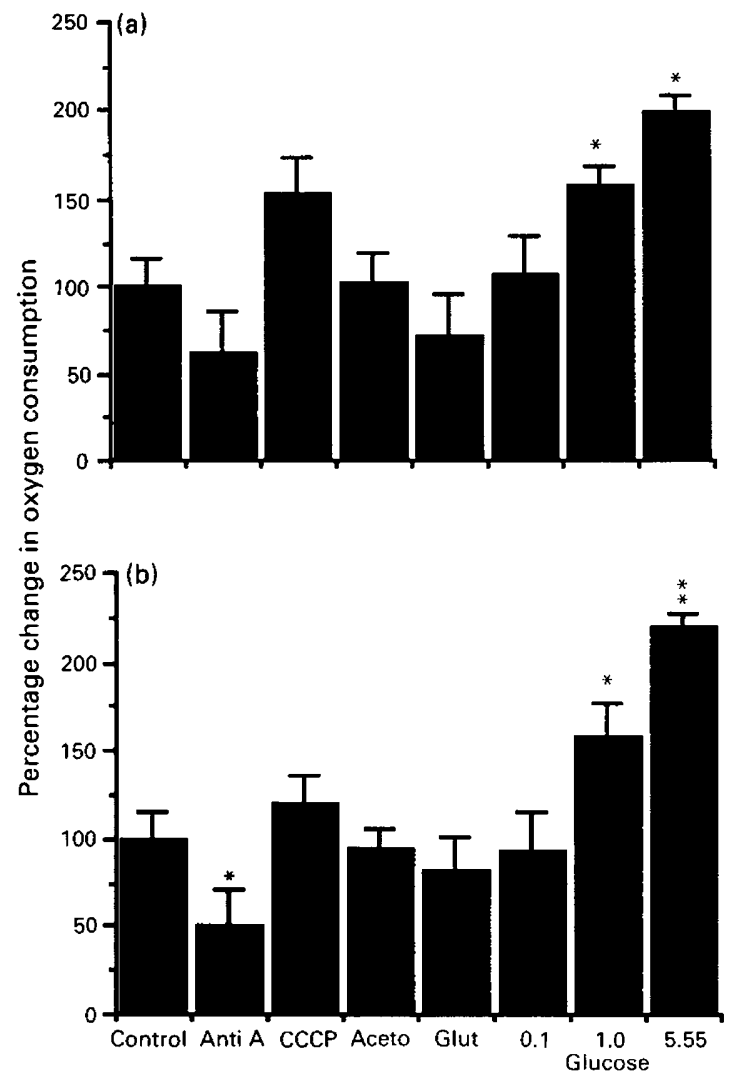

Fig. 1. Percentage change in the oxygen consumption (control = $100 \%$ ) of rabbit oviduct tissue slices in response to various compounds and potential respiratory substrates; (a) ampulla, (b) isthmus. Values are mean \pm SEM. Significantly different from control: ${ }^{*} P<0.05$ and ${ }^{* *} P<0.01$. Anti $A$ : antimycin A, CCCP: carbonyl-cyanide- $m$ chlorophenylhydrazone, Aceto: $1 \mathrm{mmol}$ acetoacetate $\mathrm{l}^{-1}$, Glut: $1 \mathrm{mmol}$ glutamine $\mathrm{l}^{-\mathrm{I}}$.

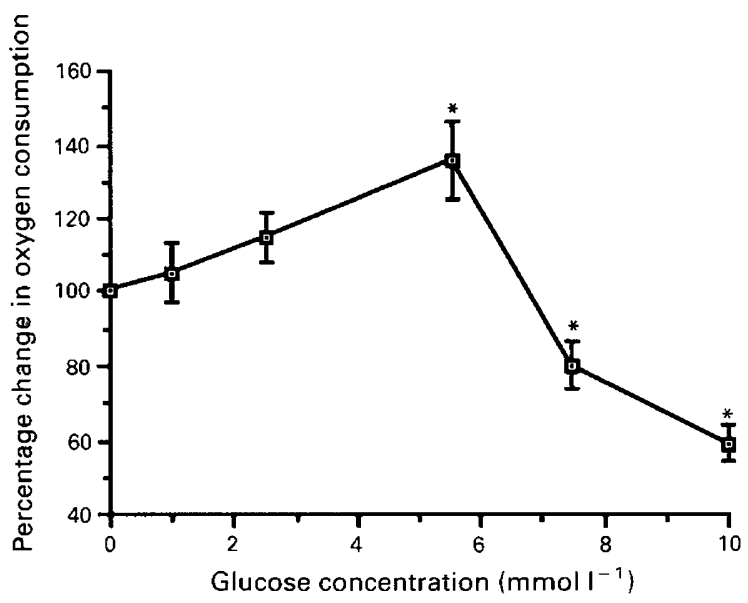

Fig. 2. Percentage change in the oxygen consumption (control = $100 \%$ ) of isolated rabbit oviduct epithelial cells in suspension with increasing glucose concentration. Values are mean \pm SEM. Significantly different from the control: ${ }^{*} P<0.001$.

Downloaded from Bioscientifica.com at 04/26/2023 09:26:13AM 


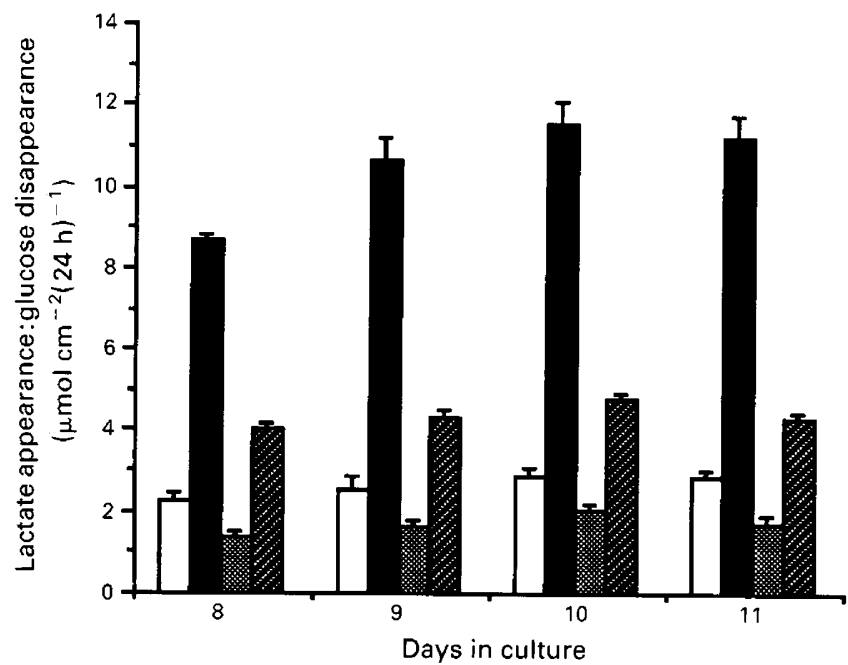

Fig. 3. ( $\square$ ) Apical and ( $\square$ ) basal lactate appearance and (图) apical and

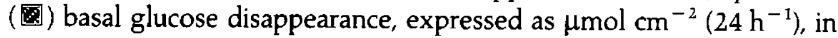
cultured oviduct epithelial cells derived from rabbits at oestrus. Values are mean \pm SEM for 8-11 days in culture.

\section{Metabolism of cultured oviduct epithelial cells from rabbits at oestrus}

The epithelial cells formed a confluent polarized monolayer as demonstrated by immunocytochemistry and electron microscopy (Dickens et al., 1993). The metabolic profile of cultured epithelial cells grown for 8-11 days after isolation from rabbits at oestrus is shown (Fig. 3). Over the 17 days, glucose disappeared preferentially from the basal as opposed to the apical side of the cultured monolayers. The total amount of glucose taken up was $5.77 \pm 0.05 \mu \mathrm{mol} \mathrm{cm} \mathrm{cm}^{-2}$ in $24 \mathrm{~h}$ $(n=204), 70 \%$ of which was accounted for by uptake from the basal medium and $30 \%$ from the apical. Lactate appeared predominantly in the basal medium: $7.34 \pm 0.19 \mu \mathrm{mol}$ $\mathrm{cm}^{-2}$ in $24 \mathrm{~h}(n=204)$ in comparison to $1.94 \pm 0.03 \mu \mathrm{mol}$ $\mathrm{cm}^{-2}$ in $24 \mathrm{~h}$ on the apical side. On the basis that one molecule of glucose gives rise to two molecules of lactate by glycolysis, $81 \%$ of the glucose disappearance could be accounted for by lactate production in the basal and apical media.

\section{Metabolism of cultured epithelial cells from rabbits 3 days after mating}

The typical metabolic characteristics of cultures established from oviducts taken from rabbits 3 days after mating is shown (Fig. 4). There was no significant difference between the values obtained with time in culture. Total glucose uptake was $3.37 \pm 0.03 \mu \mathrm{mol} \mathrm{cm} \mathrm{cm}^{-2}$ in $24 \mathrm{~h}$, a value not significantly different from that measured in cells derived from rabbits at oestrus. Again, glucose was taken up preferentially from the basal side of the cells. Lactate output also occurred predominantly in a basal direction; $6.88 \pm$ $1.39 \mu \mathrm{mol} \mathrm{cm} \mathrm{cm}^{-2}$ in $24 \mathrm{~h}$ appeared on the basal side, while $2.73 \pm 0.05 \mu \mathrm{mol} \mathrm{cm}{ }^{-2}$ in $24 \mathrm{~h}$ appeared on the apical side. While there was no significant difference in the total amount

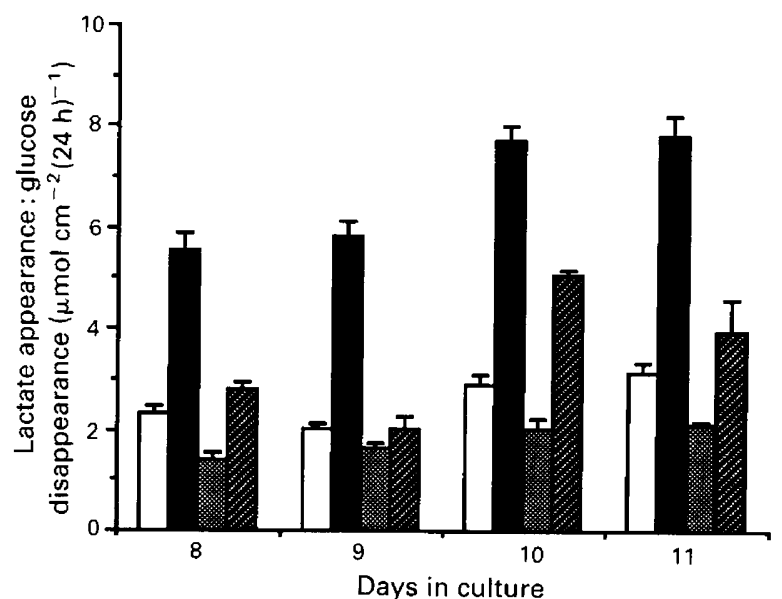

Fig. 4. ( $\square$ ) Apical and ( $\square$ ) basal lactate appearance and (圈) apical and (19) basal glucose disappearance, expressed as $\mu \mathrm{mol} \mathrm{cm} \mathrm{cm}^{-2}(24 \mathrm{~h})^{-1}$, in cultured oviduct epithelial cells derived from rabbits 3 days after mating. Values are mean \pm SEM for 8-11 days in culture.

of lactate produced between the cells derived from mated and oestrous animals, the proportion appearing on the apical side was increased, from 30 to $40 \%(P<0.001)$ in the cells derived from rabbits 3 days after mating. In contrast to the cells taken from rabbits at oestrus, 100\% of the glucose used by the epithelial cells could be accounted for by lactate formation.

\section{Glucose transport measured in Ussing chambers}

Glucose, added at a concentration of $5.55 \mathrm{mmol}^{-1}$ to the basal side of the filter only, disappeared at a rate of $1.81 \mu \mathrm{mol}$ $\mathrm{cm}^{-2} \mathrm{~h}^{-1}$ and appeared in the medium on the apical side at a rate of $0.20 \mu \mathrm{mol} \mathrm{cm} \mathrm{cm}^{-2} \mathrm{~h}^{-1}$ to give a total apical appearance, over $2.5 \mathrm{~h}$, of $0.52 \pm 0.03 \mu \mathrm{mol} \mathrm{cm}{ }^{-2}$ (Fig. 5 ). In comparison, $5.55 \mathrm{mmol}$ glucose $\mathrm{I}^{-1}$ when added to the apical side only, disappeared at a rate of $1.38 \mu \mathrm{mol} \mathrm{cm}{ }^{-2} \mathrm{~h}^{-1}$ and glucose appeared on the basal side at a low rate of $0.09 \mu \mathrm{mol} \mathrm{cm}{ }^{-2} \mathrm{~h}^{-1}$. In cells taken from rabbits 3 days after mating, the rate of glucose loss from the basal medium and its rate of appearance in the apical medium were significantly reduced, to 0.45 and $0.13 \mu \mathrm{mol} \mathrm{cm}{ }^{-2} \mathrm{~h}^{-1}$, respectively $(P<0.01)$. The resulting glucose concentration after $2.5 \mathrm{~h}$ in the apical compartment was $0.33 \pm 0.01 \mu \mathrm{mol} \mathrm{cm} \mathrm{cm}^{-2}$ (Fig. 5). Glucose was added at a concentration of $1 \mathrm{mmol} \mathrm{l}^{-1}$ to both sides of the cells to determine whether active sugar transport could take place. The final concentrations in the basal and apical fluids were $0.83 \pm 0.01$ and $0.94 \pm 0.01 \mu \mathrm{mol} \mathrm{l}^{-1}$, respectively. Characteristics of the transport of glucose were examined in epithelial cells derived from rabbits at oestrus. Phloretin $\left(0.5 \mathrm{mmol} \mathrm{l}^{-1}\right)$ was found to abolish the apical appearance of glucose added at a concentration of $5.55 \mathrm{mmol} \mathrm{l}^{-1}$ to the basal side of the cells. When $5.55 \mathrm{mmol}$ $\mathrm{L}-\left[1-{ }^{14} \mathrm{C}\right]$ glucose $\mathrm{I}^{-1}$ was added to the basal side, there was an apical appearance of $0.06 \mu \mathrm{mol} \mathrm{cm}{ }^{-2} \mathrm{~h}^{-1}$ corresponding to a total apical appearance of $0.17 \pm 0.02 \mu \mathrm{mol} \mathrm{cm} \mathrm{cm}^{-2}$ after $2.5 \mathrm{~h}$ (Fig. 6). This was significantly less than the rate of D-glucose appearance $\left(0.15 \mu \mathrm{mol} \mathrm{cm} \mathrm{cm}^{-2} \mathrm{~h}^{-1}\right)$ in control experiments $(P<0.01)$. 


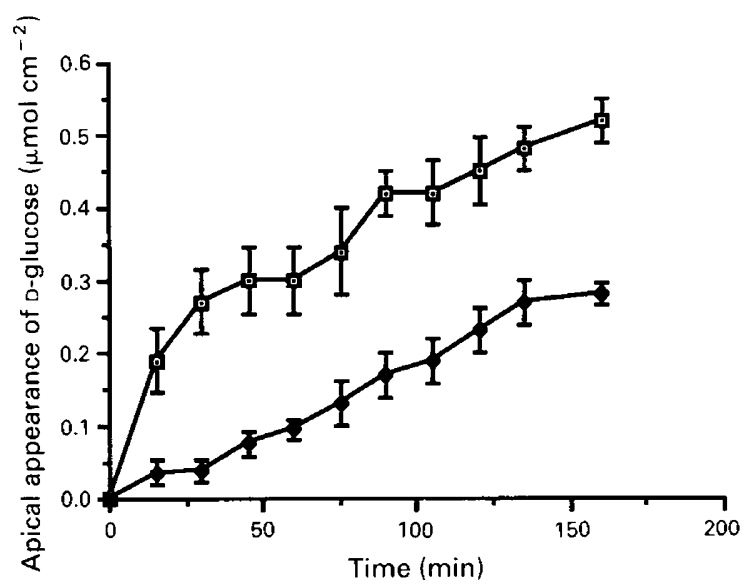

Fig. 5. Apical appearance of D-glucose $\left(\mu \mathrm{mol} \mathrm{cm}^{-2}\right)$ in Ussing Chamber preparations of polarized oviduct epithelial cells derived from rabbits at oestrus (-๑-) or 3 days after mating (-O-). D-glucose was added at a concentration of $5.55 \mathrm{mmol}^{-1}$ to the basal side. Values are mean \pm SEM.

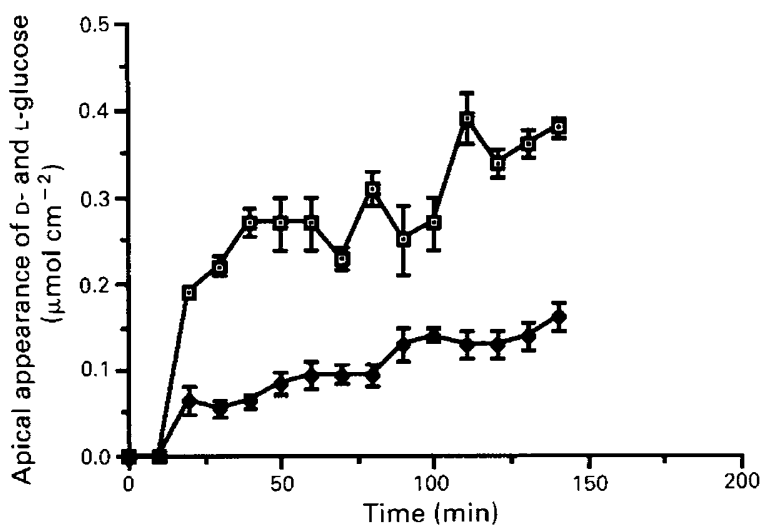

Fig. 6. Apical appearance of D- $(-\nabla-)$ and L-glucose $(-O)$ ( $\mu \mathrm{mol} \mathrm{cm}^{-2}$ ) in Ussing Chamber preparations of polarized oviduct epithelial cells derived from rabbits at oestrus. D- and L-glucose were added at a concentration of $5.55 \mathrm{mmol} \mathrm{l}^{-1}$ to the basal side. Values are mean \pm SEM.

\section{Transepithelial electrical potential difference and resistance}

Cultured cells derived from rabbits at oestrus exhibited a mean transepithelial resistance of $851.19 \pm 102.19 \mathrm{ohms} \mathrm{cm}$ $(n=38)$. The resistance of cells in cultures from rabbits 3 days after mating was significantly higher at $1467.19 \pm$ $135.94 \mathrm{ohms} \mathrm{cm}^{-2}(n=38, P<0.001)$. The potential difference had increased significantly from $-2.80 \pm 0.67 \mathrm{mV} \mathrm{cm}$ $(n=38)$ for cells from rabbits at oestrus to $-6.70 \pm 0.80 \mathrm{mV}$ $\mathrm{cm}^{-2}(n=38, P<0.001)$ in cells cultured from rabbits 3 days after mating.

\section{Discussion}

The oxygen consumption values for whole tissue slices of ampulla and isthmus were of the same order as those reported by Mastroianni et al. (1961) and Leese et al. (1981) and confirm that the oviduct is a relatively quiescent tissue, metabolically. Antimycin A reduced the oxygen consumption by $53 \%$ and CCCP increased it by $52 \%$. These responses are as predicted for these agents (Gauthier et al., 1990) and indicate that the measurements of oxygen consumption and the effects of added substrates are physiological. Of the potential respiratory substrates tested, glucose stimulated the oxygen consumption of slices of ampulla and isthmus by $99 \%$ and $120 \%$, respectively, whereas glutamine and acetoacetate had no significant effect. Brewis et al. (1992) similarly found that glucose was the substrate preferred by human fimbrial mucosal slices.

Although the respiration of the isolated epithelial cells cannot strictly be compared with that of the tissue slices, as the dry masses were obtained in different ways in the two cases, it was apparent that the oxygen consumption of cells was about half that of the tissue slices, and close to the value of $3.4 \mu \mathrm{l} \mathrm{O}_{2} \mathrm{mg}^{-1}$ dry wt $\mathrm{h}^{-1}$, reported by Brewis et al. (1992) for human fimbrial mucosa, which consists mainly of epithelial cells. The difference in oxygen consumption between the isolated epithelial cells and the whole tissue slices was not due to cellular damage as shown by the trypan blue exclusion test, but may be a result of the less physiological nature of the isolated cell preparation.

Glucose stimulated the oxygen consumption of the epithelial cells, significantly. A Crabtree effect was also observed, whereby high glucose concentrations inhibited the uptake of oxygen, a response characteristic of some tumours and cell types in culture (Mandel, 1986). A possible explanation for this phenomenon is that the rate of glycolysis increases at high glucose concentrations, leading to a fall in $A D P / P_{i}$ availability, and, hence, of oxidative phosphorylation. This is observed as a reduction in oxygen consumption (Koobs, 1972). Seshagiri and Bavister (1991) reported that the development of hamster embryos to the eight-cell stage was inhibited by glucose, and attributed this to the Crabtree effect.

Glucose is found in the lumen of the oviduct as a component of tubal fluid (Leese, 1988; Nichol et al., 1992) and makes an important contribution to the development of preimplantation embryos (Gardner and Leese, 1990). The transport of glucose was studied by plating isolated oviduct epithelial cells in primary culture on collagen-impregnated filters. Under these conditions, desmosomes are re-established leading to the formation of a polarized monolayer, which has been shown to be epithelial in culture (Dickens $e t$ al., 1993). This enables the bidirectional movement of glucose to be examined. Glucose was transported at approximately twice the rate in a basal to apical compared with apical to basal direction. The oviduct therefore displays an asymmetry characteristic of an epithelial cell layer. Furthermore, the net movement of glucose, from the basal to apical pole of the cells, corresponds to the passage of glucose from the blood to the lumen in vivo.

When glucose was present at equal concentrations on each side of the cells, there was no net movement into the apical or basal compartment, indicating the absence of active transport. Moreover, passive diffusion alone could not account for the rates of D-glucose appearance, since the flux of L-glucose across the cell monolayer was $42 \%$ that of D-glucose: L-glucose is not transported or metabolized by mammalian cells, and any movement observed is, therefore, likely to be due to passive diffusion. These data, therefore, indicate that D-glucose movement Downloaded from Bioscientifica.com at 04/26/2023 09:26:13AM 
across the rabbit oviduct epithelium is, to a considerable extent, carrier mediated. This was confirmed by experiments involving the addition of phloretin, which inhibits glucose-facilitated diffusion in erythrocytes and other systems (LeFevre and Marshall, 1959). Phloretin inhibited the apical appearance of glucose, added at a concentration of $5.55 \mathrm{mmol}^{-1}$ to the basal compartment. Facilitated diffusion was, therefore, responsible for the majority of glucose movement across the rabbit oviduct epithelium, a conclusion reached by Leese and Jeffries (1977) using an in vivo, rabbit oviduct, lumen perfusion system. Since the epithelium can take up glucose from both sides, it is likely that glucose transporters are present in the apical and basal plasma membranes. Characterization of their type, orientation, number and kinetics (Rindler, 1985) would be required to account for the asymmetrical transport of glucose across the oviduct.

Of the glucose taken up by the cells, $80 \%$ could be accounted for by the appearance of lactate in the incubation media. In addition to providing energy for the cell, such metabolism also maintains a glucose concentration gradient across the plasma membrane, favouring continued entry of sugar. Lactate was secreted, predominantly in a basal direction. Such lactate would be removed by the blood in vivo. A small amount of lactate was also released into the apical medium, where it could act as a potential energy substrate for spermatozoa and early embryos within the intact animal (Leese, 1988). The pattern of lactate appearance, as with glucose uptake, further illustrates the asymmetrical nature of oviduct epithelial cells cultured on filters.

The physiology of the oviduct changes in response to the endocrine state of the animal (Jansen, 1984). With regard to non-electrolyte transport, Leese and Gray (1985), using a combined vascular and lumen preparation of rabbit oviducts, found that glucose and lactate appearance in the lumen was low in oviducts removed from animals 3 days after treatment with hCG. It was, therefore, encouraging to discover that this response was also apparent in the epithelial cells grown in vitro, as a polarized monolayer. The rate of glucose appearance on the apical side fell dramatically in the cultures established from rabbits 3 days after mating, a difference still apparent in the cells 7 days after isolation.

Preliminary data using L-glucose and the non-metabolizable glucose analogue 3-O-methyl-D-glucopyranose indicated that there is no change in the non-saturable, passive component of glucose movement in cells taken from rabbits 3 days after mating. In other words, the carrier-mediated diffusion of glucose across the rabbit oviduct epithelium is sensitive to the endocrine state of the animal. Hormones have been shown to influence the activity of glucose transporters in other systems (Gould and Bell, 1990) and could be a contributory factor to the fall in sugar transport observed. It was also interesting to note that the electrical resistance across the oviduct epithelial cells was significantly higher in cultures from rabbits 3 days after mating compared with those from rabbits at oestrus. This observation is in agreement with the finding of Gott et al. (1988) that the potential difference across the wall of the vascularly perfused rabbit oviduct increased from 5.5 to $7.6 \mathrm{mV}$ in oviducts taken from animals treated 3 days previously with hCG.

This response in epithelial cell physiology to mating is likely to lead to changes in the composition of oviductal fluid. Gott et al. (1988) observed a $50 \%$ fall in the rate of oviduct fluid production 3 days after mating. On the basis of this finding, and the decrease in the rate of glucose transport observed in this study, the steady state concentration of glucose in rabbit oviduct fluid would be predicted to fall by about $50 \%$. In this context, it is of interest that Nichol et al. (1992) found that the glucose concentration in fluid taken from the ampulla and ampullary-isthmic junction of pig oviducts fell sharply after mating, from a pre-ovulatory value of $0.97 \mathrm{mmol} 1^{-1}$ to $0.25 \mathrm{mmol} \mathrm{l}^{-1}$. Until the specific requirements of rabbit and pig embryos for nutrients are defined, the significance of these observations remain unclear. In the case of the rabbits, the fall in glucose concentration on day 3 of pregnancy would coincide with the passage of the embryos into the uterus when any requirement for glucose in the oviduct had passed.

In conclusion, hormone-induced changes in oviduct physiology and biochemistry in vivo are retained in isolated epithelial cells grown as a polarized monolayer in primary culture. This preparation will enable the mechanisms involved in the transepithelial movement of other non-electrolytes as well as electrolytes across the oviduct epithelium to be studied in detail.

The study received financial support from the Science and Engineering Research Council awarded to L. J. Edwards, and from the Medical Research Council to H. J. Leese.

\section{References}

Bradford MM (1976) A rapid and sensitive method for the quantitation of micrograms of protein utilizing the principle of protein-dye binding Analytical Biochemistry 72 248-254

Brewis IA, Winston RML and Leese HJ (1992) Energy metabolism of the human Fallopian tube Journal of Reproduction and Fertility 95 257-262

Dickens CJ, Southgate J and Leese HJ (1993) Use of primary cultures of rabbit oviduct epithelial cells to study the ionic basis of tubal fluid formation Journal of Reproduction and Fertility $98603-610$

Gardner DK and Leese HJ (1990) Concentrations of nutrients in mouse oviduct fluid and their effects on embryo development and metabolism in vitro Journal of Reproduction and Fertility 88 361-368

Gauthier T, Denis-Pouxviel C and Murat JC (1990) Respiration of mitochondria isolated from differentiated and undifferentiated HT29 colon cancer cells in the presence of various substrates and ADP generating systems International Journal of Biochemistry 22 (No. 4), 411-417

Gould GW and Bell GI (1990) Facilitative glucose transporters: an expanding family Trends in Biochemical Sciences 13 18-23

Gott AL, Gray SM, James AF and Leese HJ (1988) The mechanism and control of rabbit oviduct fluid formation Biology of Reproduction 39 758-763

Jansen RPS (1984) Endocrine response in the Fallopian tube Endocrine Reviews 5 (No. 4), 525-551

Kimber SJ, Waterhouse R and Lindenberg MA (1993) In vitro models for implantation in the mammalian embryo. In Preimplantation Embryo Development, Serono Symposia pp. 243-263 USA Ed BD Bavister. Springer-Verlag, New York.

Koobs DH (1972) Phosphate mediation of the Crabtree and Pasteur effects Science 178 127-133

Leese HJ (1988) The formation and function of oviduct fluid Journal of Reproduction and Fertility $\mathbf{8 2} 84.3-856$

Leese HJ and Bronk JR (1972) Automated fluorometric analysis of micromolar quantities of ATP, glucose and lactic acid Analytical Biochemistry 45 211-221

Leese HJ \& Gray SM (1985) Vascular perfusion: a novel means of studying oviduct function American Journal of Physiology 248 E624-E632

Leese HJ and Jeffries KS (1977) Evidence for the facilitated diffusion into the rabbit oviductal fluid Journal of Reproduction and Fertility 51 93-97

Downloaded from Bioscientifica.com at 04/26/2023 09:26:13AM 
Leese HJ, Humpherson PG and Jefferies KS (1981) Two preparations for the study of the isolated rabbit oviduct Journal of Reproduction and Fertility 63 249-255

LeFevre PG and Marshall JK (1959) The attachment of phloretin and analogues to human erythrocytes in connection with inhibition of sugar transport Journal of Biological Chemistry 234 3022-3026

McCormack SA and Glasser SR (1980) Differential response of individual uterine cell types from immature rats treated with estradiol Endocrinology 106 1634-1649

Mandel LJ (1986) Energy metabolism of cellular activation, growth and transformation. In Current Topics in Membranes and Transport 27 pp 261-291. Academic Press Inc., New York

Mastroianni L, Jr, Forrest $W$ and Winternitz WW (1961) Some metabolic properties of the rabbit oviduct Proceedings for the Society of Experimental Biology and Medicine 107 86-88
Newsholme EA and Leech AR (1983) The oxidation of acetyl-coenzyme A. In Biochemistry for the Medical Sciences pp 146. John Wiley \& Sons, Chichester Nichol R, Hunter RHF, Gardner DK, Leese HJ and Cooke GM (1992) Concentrations of energy substrates in oviductal fluid and blood plasma of pigs during the peri-ovulatory period Journal of Reproduction and Fertility 96 $1-9$

Rindler MJ (1985) Biogenesis of plasma membranes in polarized epithelial cells Biochemical Society Transactions 14 159-161

Seglen PO (1976) Preparation of isolated rat liver cells. In Methods in Cell Biology $1329-79$

Seshagiri PB and Bavister BD (1991) Inhibition of hamster 8-cell embryo development in vitro by glucose and phosphate is associated with decreased respiration and oxidative activity Molecular Reproduction and Development 30 $105-111$ 